\title{
In-Flow DNA Extraction Using on-Chip Microfluidic Amino-Coated Silicon Micropillar Array Filter
}

\author{
Hanaa M Hegab ${ }^{1,2,3,4 *}$, Soliman $\mathbf{M}^{3}$, Ebrahim $\mathbf{S}^{3}$ and Op de Beeck $\mathbf{M}^{2}$ \\ ${ }^{1}$ KACST-Intel Consortium Center of Excellence in Nano-manufacturing Applications (CENA), Riyadh, Saudi Arabia \\ ${ }^{2}$ Imec, Kapeldreef 75, Leuven, Belgium \\ ${ }^{3}$ Institute of Graduate Studies and Research, Alexandria University, Alexandria, Egypt \\ ${ }^{4}$ Institute of Advanced Technology and New Materials, City of Scientific Research andTechnological Applications, Borg Elarab, Alexandria, Egypt
}

\begin{abstract}
A silicon micropillar filter ( $\mu \mathrm{PF}$ ) chip was fabricated, glass-bonded, coated with 3-aminopropyltriethoxysilane (APTES) then tested for its ability to bind and release pre-purified DNA in continuous flow mode. APTES coated MPF was tested over different DNA initial loading amounts and flow rates. Simple and effective washing and eluting steps were used, which allowed direct detection of obtained DNA using UV Nano-Droplet. Both the capture efficiency and elution $\%$ were inversely proportional to flow rate, with such relation being more profound at higher DNA concentration. DNA elution recovery $\%$, as high as $80 \%$, was achieved under flow rate of $5 \mu \mathrm{l} / \mathrm{min}$ and an initial DNA loading of $250 \mathrm{ng}$. The capture capacity per surface area of the APTES-coated $\mu$ PFis $\sim 186 \mathrm{ng} / \mathrm{cm}^{2}$, which mounts to $\sim 3.7$ times the capacity of an identical uncoated filter. These results demonstrate the potential for integrating such amino-coated $\mu \mathrm{PF}$ in a lab-on-a-chip system for the extraction of nucleic acids directly from clinical samples in a continuous flow mode.
\end{abstract}

Keywords: Micropillar filter; DNA extraction on chip; APTES; Continuous flow

\section{Introduction}

The prospect for the commercialization of microfluidic LOC systems has powered over the recent decade, in particular for medical and the life science diagnostic applications. This development has been prompted by creating massive surface area such as integrated architectures, and extremely functional lab-on-a-chip technologies [1]. Towards commercialization, there is a need for economic manufacture which involves optimized cost for materials and high affinity for DNA separation for a range of back-end processing steps, such as surface modification of solid phase integrated architectures. The development of micro total DNA analysis systems ( $\mu$ TAS) has shown a large potential to integrate sample preparation and target amplification as well as detection in a single disposable cartridge. The DNA extraction step has been shown to play an important role in various subsequent analysis steps, including Polymerase Chain Reactions (PCR) [2], DNA hybridization [3], DNA biosensors [4], capillary electrophoresis [5], etc. Despite its importance and a plethora of available DNA extraction techniques, new methods to further simplify DNA extraction directly on chip are still needed, specially, as many methods use reagents or operational steps that are not compatible with standard microfluidic devices. For example, traditional chemical DNA extraction techniques entail the use of centrifugation and organic solvents to purify DNA.

Microfluidics Solid Phase Extraction (SPE) methods may provide an alternative to traditional DNA extraction methods, allowing for more rapid and straightforward on-chip sample preparation. Most SPE methods use silica as the solid phase, with chaotropic salts to bind DNA. Some researchers used micropillar chip to purify DNA from a whole blood sample, based on chaotropic salts [6]. High concentrations of chaotropic salts are, however, often difficult to remove from the sample and may inhibit following PCR reactions or other molecular techniques [7]. A possible solution was provided by Melzak et al. [8] where it was shown that after DNA binding to silica in the presence of chaotropic salts, elution at a low ionic strength could be achieved. Additionally, micro-sized SPE methods come with a number of additional inherent advantages, such as compact reagent consumption, avoidance of cross-contamination, and the possibility of direct integration with downstream methods like PCR, detection or electrophoretic separation [9-12].

Silica has been utilized in micro-scale devices to extract DNA from complex biological samples with volumes on the order of tens of microliters [13]. Some other efforts to miniaturize DNA extraction by providing a large surface area to volume ratio has been described using silica resins or beads in a capillary system [14]. Other systems included micro-fabricated silica pillars to increase the surface area within the micro-channel by $300-600 \%$ [15]. Although the binding capacity in such micro-chip reached approximately $82 \mathrm{ng} / \mathrm{cm}^{2}$, the elution was limited to only $10 \%$ of loaded-DNA. To solve this issue, another researcher used functionalization of micro- or nanoparticles to provide massive active surface areas [16-18]. Recently, a bead-packed microfluidic device with a built-in flexible wall was developed by Hwang et al. [19] to automate extraction of nucleic acids from Methicillin-Resistant Staphylococcus aureus (MRSA) in nasal swabs. A flexible PolyDiMethylsiloxane (PDMS) membrane was designed to manipulate the Surface-to-Volume Ratio (SVR) using positively charged polyethylene imine PEI coated beads-packed chambers. That device captured DNA electrostatically in the range of $0.05-0.15 \mu \mathrm{m}^{-1}$ and demonstrated a typical SPE protocol composed of binding, washing, and eluting. Mixing by asynchronous membrane vibration during the eluting step enabled ca. 90\% DNA recovery with ca. $10 \mu \mathrm{l}$ of liquid solution from the captured cells on the bead surfaces.

*Corresponding author: Hanaa M Hegab, IMEC, Kapeldreef 75, Leuven, Belgium, Tel: +32488694814; E-mail: hana_hegap@yahoo.com

Received July 28, 2013; Accepted August 29, 2013; Published September 05 2013

Citation: Hegab HM, Soliman M, Ebrahim S, Op de Beeck M (2013) In-Flow DNA Extraction Using on-Chip Microfluidic Amino-Coated Silicon Micropillar Array Filter. J Biosens Bioelectron 4: 140. doi:10.4172/2155-6210.1000140

Copyright: @ 2013 Hegab HM, et al. This is an open-access article distributed under the terms of the Creative Commons Attribution License, which permits unrestricted use, distribution, and reproduction in any medium, provided the original author and source are credited. 
Although the effectiveness of APTES in immobilizing DNA has been demonstrated and studied by many researchers on different devices [20], to the best of our knowledge, the work presented here is the first attempt to coat a glass-bonded $\mu$ PFchip with APTES and use it in demonstrating successful extraction of bacteriophage lambda DNA ( $\lambda \mathrm{DNA})$, as a preliminary step towards DNA extraction from blood. The use of the pre-purified $\lambda \mathrm{DNA}$ at this stage stemmed from the need to determine the purification efficiency of amino-coated $\mu \mathrm{PF}$ with high accuracy. In this study, $\mu \mathrm{PF}$ chips were fabricated for the purpose of DNA extraction under continuous flow conditions. The filters were made out of silicon and coated with APTES in-flow pass. The binding efficiency of such amino-coated $\mu \mathrm{PF}$ was investigated and compared to the efficiency of uncoated filters under the same conditions. In addition, we propose a simple and effective washing and eluting steps based on using pure water at $80^{\circ} \mathrm{C}$, which allows direct detection of collected DNA using UV Nano-Droplet without the need of fluorescence intercalating dyes and fluorescence measurement tools, as is common when using chaotropic salts or eluting DNA with high concentrated buffers.

\section{Materials and Methods}

\section{Materials and experimental consideration}

In this study, used bacteriophage lambda DNA ( $\lambda$ DNA) was purchased from Invitrogen (Carlsbad, CA). Sulfuric acid $(98 \% \mathrm{v} / \mathrm{v})$ and hydrogen peroxide $(30 \% \mathrm{v} / \mathrm{v})$ were obtained from Fluka (USA), while all other reagents, including 3 aminopropyltriethoxysilane (APTES) and Sybr Green dye were purchased from Sigma-Aldrich (USA). The $150 \mathrm{mM}$ phosphate buffer solution (PB) $\mathrm{pH} 7.4$ was prepared in the lab prior to use.

The $\mu \mathrm{PF}$ was fabricated using Deep Reactive Ion Etching (DRIE), as described earlier [21]. The $\mu \mathrm{PF}$ was sealed by a Pyrex glass wafer using anodic bonding. In this work only micropillar filters with a pillar diameter of $15 \mu \mathrm{m}$ and an inter-pillar distance of $5 \mu \mathrm{m}$ were used. The filter channels were $4.3 \mathrm{~mm}$ wide and $7.3 \mathrm{~mm}$ long and contained a regular array of 43,000 pillars, each pillar being $300 \mu \mathrm{m}$ high. Hence pillar filter has a total surface area of $6.6 \mathrm{~cm}^{2}$ and a total volume of $4.9 \mu \mathrm{l}$. The microstructure of the fabricated filter was imaged using scanning electron microscope, as depicted in Figure 1.The experimental setup requires the filter to be clamped between aluminum plates and connected to a syringe pump [NE-1010, Pro sense (withdraw type). B.V, USA] using fused silica capillaries of $280 \mu \mathrm{m}$ inner diameter. These capillaries were connected to the filters by means of Nano Tight ${ }^{\mathrm{TM}}$ unions and fittings. The set-up is shown in Figure 2. To control the injection and withdraw of a certain volume, a well-controlled injection loop was utilized. To switch between injection, washing or elution fluid, a rotational valve (Lab smith MV201-T116, USA) was used.

\section{Modification of $\mu$ PF surface with APTES}

Filters were cleaned with piranha $\left(3 \mathrm{H}_{2} \mathrm{SO}_{4}: 1 \mathrm{H}_{2} \mathrm{O}_{2}\right)$ and dried on a hot plate at $110^{\circ} \mathrm{C}$ for 15 minutes before silanization. That particular piranha clean step was applied to all filters used in this work, including the uncoated filter. The silanization protocol used was an optimized surface modification process for DNA capture and release [22]. Based on that study, a $50 \mu$ l of APTES solution in water $(3 \mathrm{v} / \mathrm{v} \%)$ was injected into the $\mu \mathrm{PF}$ at a flow rate of $1 \mu \mathrm{min}^{-1}$ and then the filter surface was silanized for $30 \mathrm{~min}$. The $\mu \mathrm{PF}$ was then washed twice with deionized water to remove any unbounded APTES. After washing, the filters were cured at $80^{\circ} \mathrm{C}$ for 4 hours then allowed to cool down to room temperature before use.

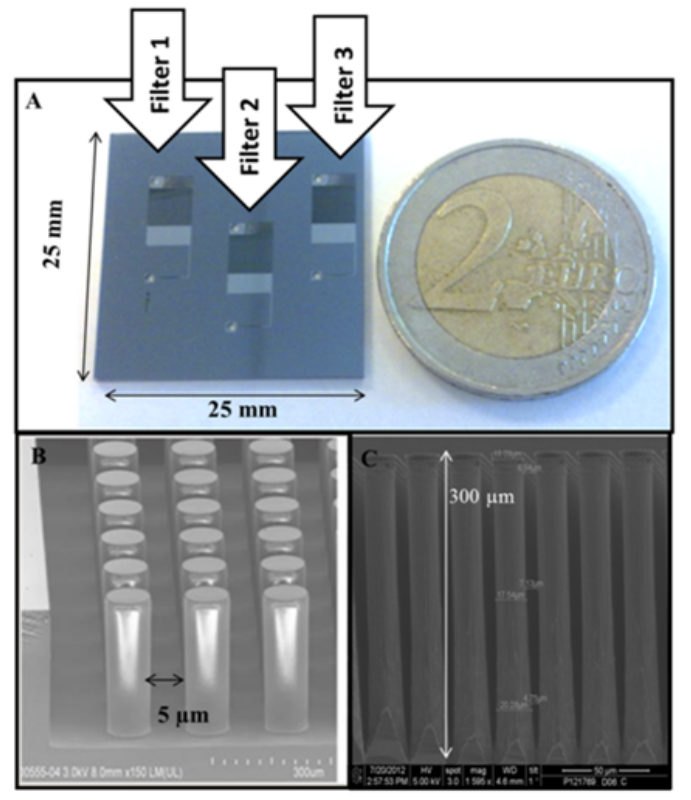

Figure 1: (A) A micropillar filter chip image which contains three devices, filter 2 was used for this experiment being $4300 \mu \mathrm{m}$ wide, $7300 \mu \mathrm{m}$ long and $300 \mu \mathrm{m}$ deep. (B) Scanning electron microscope images of the Si $\mu \mathrm{PF}$ fabricated using deep reactive ion etch, showing a tilted view of the cylinder-shaped micropillars and $(C)$ a magnified view of micropillars array.

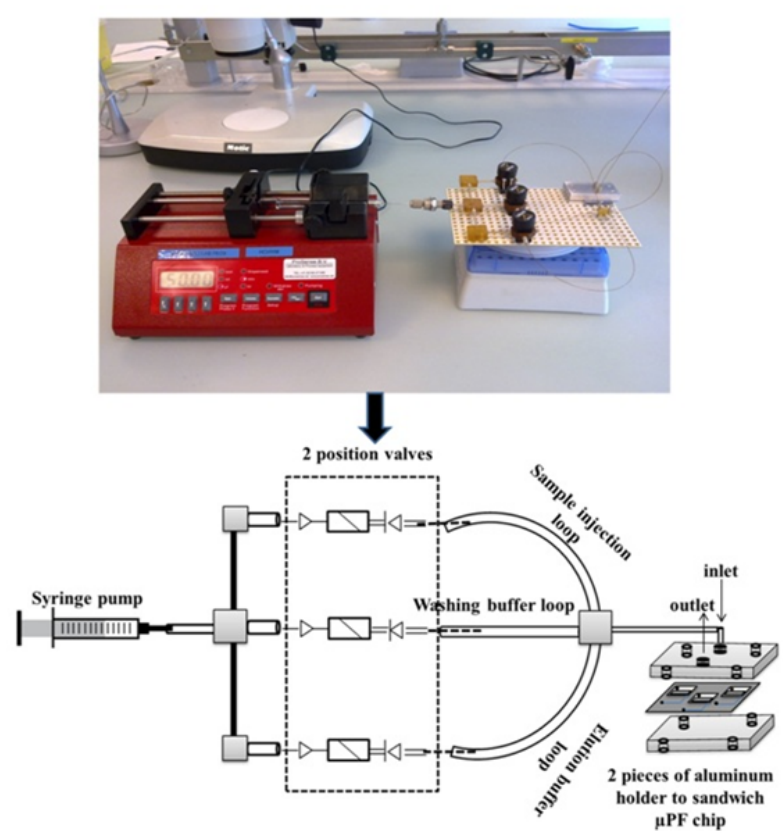

Figure 2: Real and schematic diagram of the continuous flow DNA purification set-up using the $\mu \mathrm{PF}$ chip.

\section{Characterization of $\mu \mathrm{PF}$ performance}

To assess the $\mu \mathrm{PF}$ performance, $\lambda \mathrm{DNA}$ was captured and eluted after washing using a continuous flow process. To introduce the DNA into the $\mu \mathrm{PF}$ filter, a sample loop of $10 \mu \mathrm{l}$ was filled with purified $\lambda \mathrm{DNA}$, with concentrations ranging from $25-300 \mathrm{ng} / \mu \mathrm{l}$ dissolved in $150 \mathrm{mM}$ $\mathrm{PB}(\mathrm{pH} 7.4)$, i.e. the total initial DNA loading ranged between 250 
$3000 \mathrm{ng}$ for the various tests performed. For the DNA capturing step, the full content of the sample loop was injected inside the filter from the entrance side and collected at the exit side, in order to determine the amount of $\lambda$ DNA that was not trapped. Afterwards, the $\mu$ PF chip was rinsed with $25 \mu \mathrm{PBS}$, and eluents were collected, to determine the amount of $\lambda$ DNA eluted during this washing step. Finally, to elute the captured $\lambda \mathrm{DNA}$, the elution loop was loaded with water at $80^{\circ} \mathrm{C}$ using flow rate of $100 \mu \mathrm{l} / \mathrm{min}$ via the withdraw option on the automatic syringe pump (time elapsed $=15 \mathrm{sec}$ ), then $25 \mu \mathrm{l}$ of water at $80^{\circ} \mathrm{C}$ was flushed through the filter with flow rate of $50 \mu \mathrm{l} / \mathrm{min}$ and again, $\lambda \mathrm{DNA}$ aliquots were collected (see Figure 2). It should be emphasized that neither the water temperature inside the capillary nor at the exit of the $\mu \mathrm{PF}$ are known. Due to the good thermal conductivity of the silicon substrate, it is likely that temperature slightly drops below $80^{\circ} \mathrm{C}$ during the process. In addition to evaluating the filters using various $\lambda \mathrm{DNA}$ loadings, also flow rate variations ranging from $5-50 \mu \mathrm{l} / \mathrm{min}$ were examined.

Fluorescence detection using UV inverted microscopy was utilized to visualize the $\lambda \mathrm{DNA}$ during the extraction process. Taking advantage of the transparent anodic bonded glass side of $\mu \mathrm{PF}$, the chip was sandwiched between an inverted microscope camera and a flexible aluminum holder, in order to capture images of $\lambda$ DNA extraction inside the $\mu \mathrm{PF}$ after injection, washing and elution steps. To stain the $\lambda$ DNA sample, Syber Green dye with dilution of 1:10,000 was used. It is recommended to keep the solution with diluted dye in the freezer overnight and keep it away from direct light prior to usage.

To highlight the benefits of the APTES coating, an uncoated $\mu \mathrm{PF}$ was also included in the study and was tested with the highest DNA initial loading (i.e., $3000 \mathrm{ng}$ ). It should be noted that the uncoated $\mu \mathrm{PF}$ was also cleaned with piranha $\left(3 \mathrm{H}_{2} \mathrm{SO}_{4}: 1 \mathrm{H}_{2} \mathrm{O}_{2}\right)$ and dried on a hot plate at $110^{\circ} \mathrm{C}$ for 15 minutes before exposure to $\lambda$ DNA. For all collected samples (unbound, washed and eluted fractions) the $\lambda \mathrm{DNA}$ concentrations were determined by UV measurements (Nano-Droplet 2000, Thermo Scientific).

\section{Results}

\section{Fluorescence visualization of $\lambda \mathrm{DNA}$ extraction}

By examining the fluorescence intensity from the images of injected stained sample, obtained by inverted microscope, one can assess whether the DNA was trapped or not. For example, if the fluorescence intensity remains the same after washing this indicates DNA trapping. The inverted microscope images of the injected stained sample indicate that the amino coated $\mu \mathrm{PF}$ trapped most of the $\lambda \mathrm{DNA}$, as shown in Figure 3, for the test with $500 \mathrm{ng} \lambda \mathrm{DNA}$ loading of the injection fluid. After washing the $\mu \mathrm{PF}$ with $25 \mu \mathrm{l} \mathrm{PB}$, almost the same fluorescence intensity level was observed, as indicated in Figure 3B, which proves that the $\lambda \mathrm{DNA}$ is trapped by the $\mu \mathrm{PF}$. However, after flowing $12.5 \mu \mathrm{l}$ of water at $80^{\circ} \mathrm{C}$ through the $\mu \mathrm{PF}$, most of the $\lambda \mathrm{DNA}$ was eluted, as shown in Figure 3C and Figure 3D, depicting the reduction in fluorescence intensity after a partial elution step. This demonstrates the possibility of achieving complete elution of the captured $\lambda$ DNA by merely using water at $80^{\circ} \mathrm{C}$

\section{Effect of flow rate}

Figure 4 illustrates the influence of sample flow rate on the purification profile of DNA using amino-coated $\mu \mathrm{PF}$ with various initial DNA loading. For each initial DNA loading tested, the nontrapped, washed and eluted concentration of DNA collected upon exiting the $\mu \mathrm{PF}$ is determined and plotted. For comparison, tests are also performed on an uncoated $\mu \mathrm{PF}$, using an initial DNA loading of
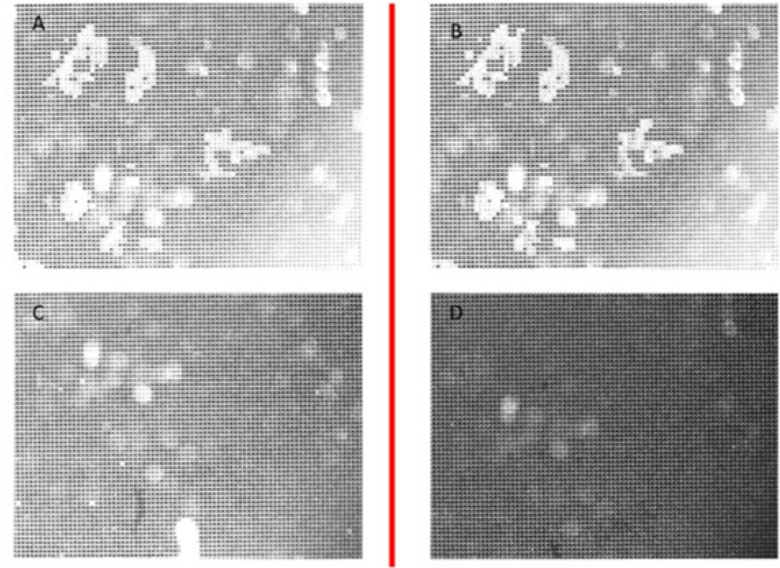

Figure 3: Inverted microscope (IM) image of Syber Green stained $\lambda$ DNA trapped to amino coated $\mu \mathrm{PF}$ (A) after injection step, (B) after a washing step with $25 \mu \mathrm{l} P B,(C)$ after a first elution step with $12.5 \mu \mathrm{l}$ of water at $80^{\circ} \mathrm{C}$, and (D) after a second elution step with $12.5 \mu$ l of water at $80^{\circ} \mathrm{C}$.
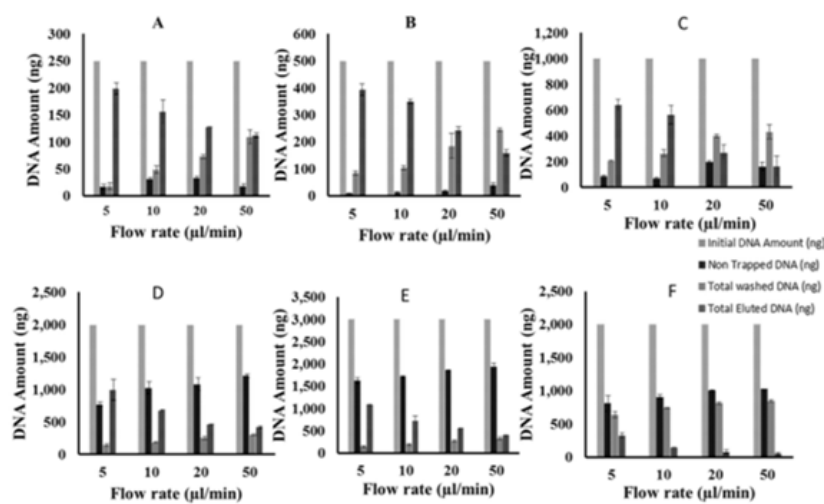

Figure 4: Purification profile of DNA using an amino-coated $\mu \mathrm{PF}$ as a function of flow rate corresponding to an initial loading of (A) $250 \mathrm{ng}$, (B) $500 \mathrm{ng}$, (C) $1000 \mathrm{ng}$, (D) $2000 \mathrm{ng}$, (E) $3000 \mathrm{ng}$. For comparison, the performance of an uncoated $\mu \mathrm{PF}$ using $2000 \mathrm{ng}$ of intial DNA loading is shown in (F). Columns represent (left to right) the initial, non-trapped, washed and eluted DNA fragments from $\mu \mathrm{PF}$ during purification process.

$2000 \mathrm{ng}$. The measurements of the corresponding DNA concentrations during the various stages of the DNA extraction process using the uncoated $\mu \mathrm{PF}$ are plotted in Figure $4 \mathrm{~F}$.

It can clearly be seen that the effect of flow rate on the concentration of collected non-trapped DNA is limited (higher flow rate gives only slightly higher amount of non-trapped DNA) when the initial amount of introduced DNA is lower than $1000 \mathrm{ng}$. Remarkably, for DNA loading $2000 \mathrm{ng}$ and higher, the flow rate influence on nontrapped DNA becomes more important. In such case, the amount of collected non-trapped DNA is about $50 \%$ of the amount present in the introduced sample, regardless of the flow rate. This may suggest that a level of saturation has been reached. Hence the amount of introduced DNA is divided between a portion strongly captured by the filter and another that is loosely attached to other surfaces on the filter. While the loosely attached DNA is removed during the washing step, the captured DNA is collected only during the final elution step. As expected, for the uncoated filter, the amount of washed DNA is quite high, indicative of lack of strong binding between the DNA and the filter, as reflected in 
Citation: Hegab HM, Soliman M, Ebrahim S, Op de Beeck M (2013) In-Flow DNA Extraction Using on-Chip Microfluidic Amino-Coated Silicon Micropillar Array Filter. J Biosens Bioelectron 4: 140. doi:10.4172/2155-6210.1000140

Page 4 of 6

Figure 4F. Comparing the results using an amino-coated and uncoated filter with same initial DNA loading (Figures $4 \mathrm{D}$ and $4 \mathrm{~F}$, respectively), it is obvious that the majority of the DNA is bound successfully to the coated $\mu \mathrm{PF}$ surfaces and is collected only during the elution step. Although the flow rate has no important influence on the DNA trapping, it has a clear influence on final DNA elution. For all initial DNA loadings, a higher flow rate results in more DNA loss during the washing step, which results in a smaller DNA collection during the final elution step. This effect is seen for both, amino-coated and uncoated filters. So the so-called 'DNA capture efficiency' is clearly dependent on flow rate. For a fixed initial $\lambda$ DNA amount, this dependence of capture efficiency on flow rate was investigated in more detail, with flow rates ranging from 5-50 $\mu \mathrm{l} / \mathrm{min}$. As can be clearly deducted from Figure 5 , the capture efficiency is significantly higher with lower flow rate. This effect is more pronounced when higher initial DNA loadings are applied. For example, at $2000 \mathrm{ng}$ of initial $\lambda$ DNA loading and a flow rate of $5 \mu \mathrm{l} / \mathrm{min}$, the capture efficiency for the coated and uncoated $\mu \mathrm{PF}$ decreased from 52 to $23 \%$ and from 18 to $3 \%$, respectively, compared to that measured at the low flow rate of $50 \mu \mathrm{l} / \mathrm{min}$, as shown in Figure 6 . Similar to the

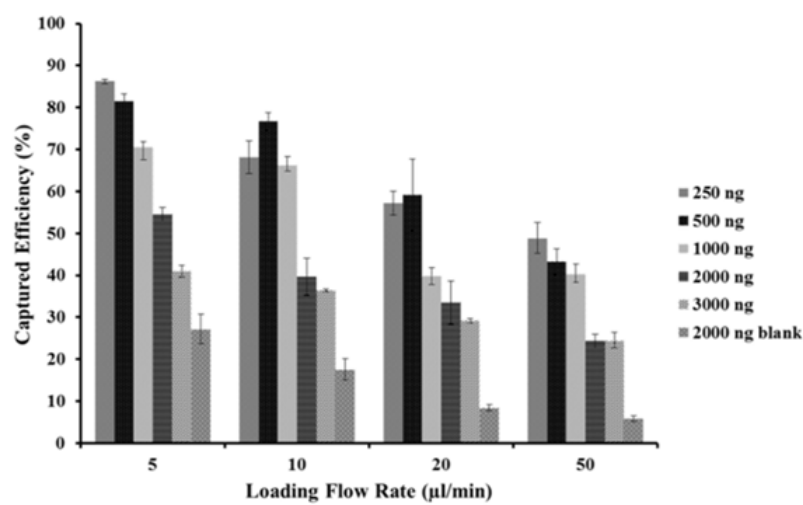

Figure 5: The effect of different loading flow rates $(5,10,20$ and $50 \mu \mathrm{l} / \mathrm{min})$ on captured DNA efficiency using an amino-coated $\mu \mathrm{PF}$ and an uncoated filter (results with label ' $2000 \mathrm{ng}$ blank'). Various initial DNA concentrations are tested as indicated in the legend.

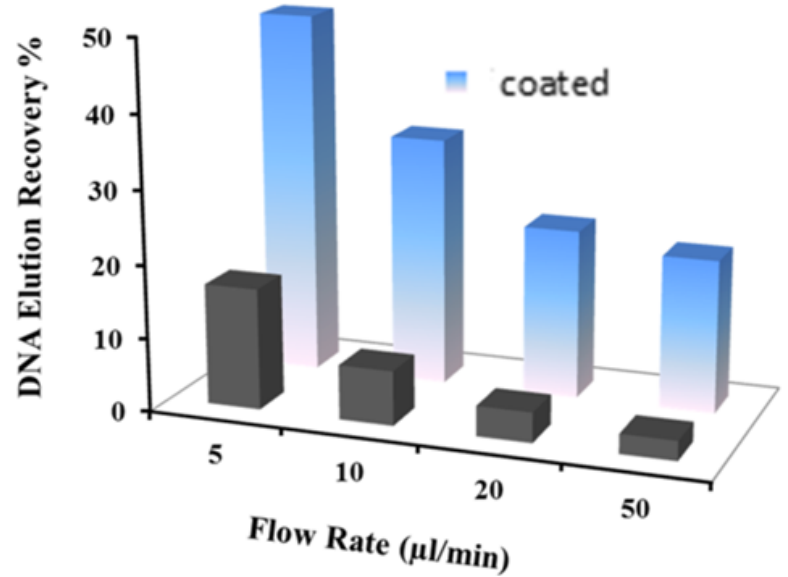

Figure 6: Purification profile of pre-purified DNA (2000 ng initial loading) using coated (blue) and uncoated (black) $\mu \mathrm{PF}$ as a function of loading flow rate.

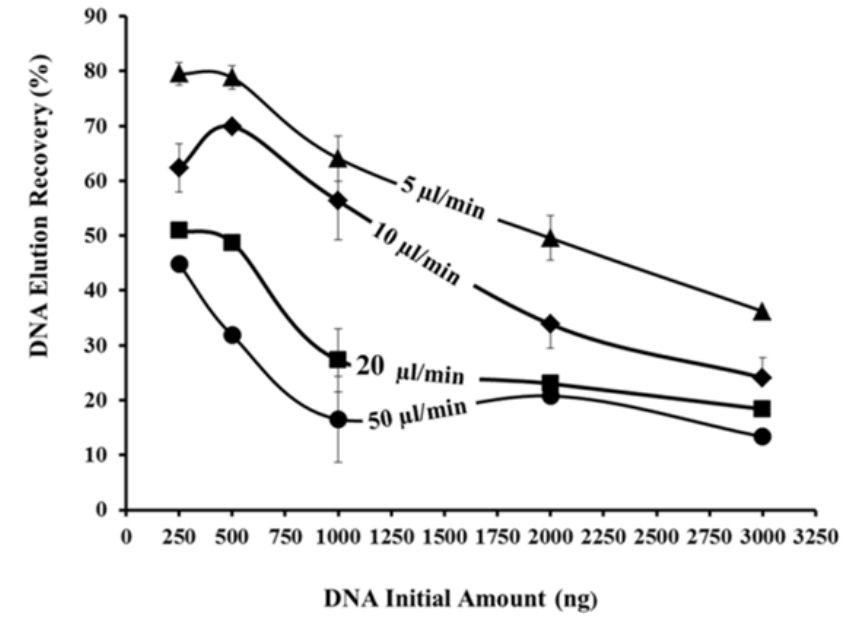

Figure 7: DNA elution recovery \% profile of pre-purified DNA using aminocoated $\mu \mathrm{PF}$ as a function of flow rate.

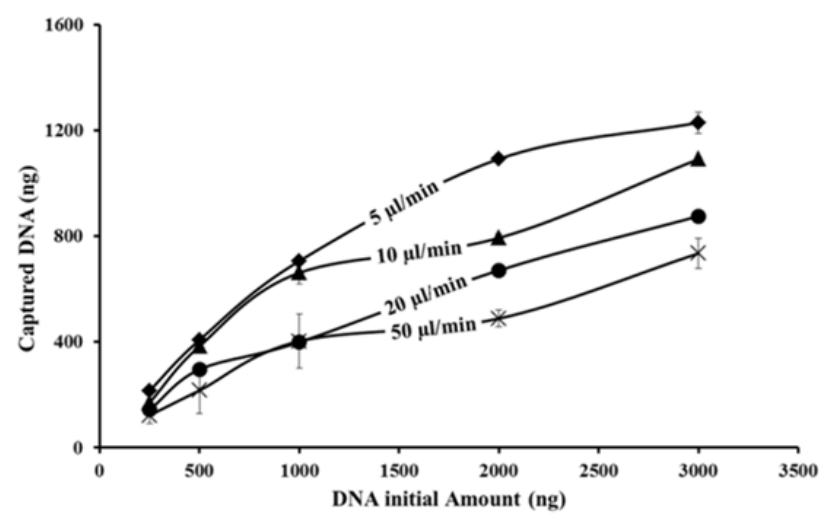

Figure 8: Amount of captured DNA using amino-coated $\mu$ PF versus initial DNA loading. Each curve is labeled with the flow rate used. For filtering with $5 \mu \mathrm{l} / \mathrm{min}$ flow rate, the saturation region of filter efficiency, being around $3000 \mathrm{ng}$, is clearly visible.

capture efficiency trend with the flow rate, the elution recovery $\%$ is significantly decreasing with increasing the flow rate over the tested range, as shown in Figure 7. The trend is also a strong function of the initial DNA loading.

\section{Effect of initial $\lambda$ DNA loading}

As portrayed in Figure 4, the captured amount of $\lambda$ DNA by the amino-coated $\mu \mathrm{PF}$ is proportional to the initial $\lambda \mathrm{DNA}$ loading (ng). In Figure 8, the amount of captured DNA is plotted versus the initial DNA loading of the injected samples, for various flow rates. The graphs show clearly that lower flow rates give better filtering results for all initial DNA loadings. Furthermore, the results strongly suggest that a saturation in filtering efficiency exists; the curves in Figure 8 all show initially a strong increase in captured DNA with increasing DNA loading, but a clear flattening occurs for higher DNA loadings. Based on the tested range of initial DNA amounts, the saturation of the filter is estimated to be $\sim 1229 \pm 42 \mathrm{ng}$ for in-flow rate of $5 \mu \mathrm{l} / \mathrm{min}$. High loading levels of DNA are likely to be flushed away without adhering to the filter surface 
probably due to the DNA capturing saturation of the pillar surface, as described before in this study.

Considering the effect of the flow rate and its relation to DNA loading, samples with smaller amounts of DNA are better suited for extraction by the amino-coated $\mu \mathrm{PF}$. The combination of low initial loading levels and low flow rates (such as 5 and $10 \mu \mathrm{l} / \mathrm{min}$ ) greatly enhances the probability of DNA adhering to available APTES molecules, resulting in much better results. A compromise between the initial DNA loading and flow rate is to be made according to the specific experimental conditions being employed. The difference of the amount of DNA captured in APTES-coated and uncoated $\mu$ PF was was consistent with the presence of amino groups introduced on the surface during filter coating. Therefore these results suggest that DNA collection, based on electrostatic interaction between positive charge of APTES amino group and negative charge of DNA sample, was successfully achieved.

\section{Discussion}

In this study, the fabricated and tested $\mu \mathrm{PF}$ features pillars have a remarkably high aspect ratio, resulting in pillars of $300 \mu \mathrm{m}$ high. This drastically increased the total pillar surface area of the filter from 0.07 $\mathrm{cm}^{2}$ (without pillars) to $6.6 \mathrm{~cm}^{2}$, producing a $1.35 \mathrm{~cm}^{2} / \mu \mathrm{l}$ surface area to volume ratio. To put this in perspective, this surface area to volume ratio is $>90$ times larger than that of a filter without pillars having the same macroscopic layout area, and is similar to the $200 \mu \mathrm{m}$ deep microfluidic DNA extraction device reported by Christel et al. [23]. However, purification of DNA had been also achieved using chaotropic salts, which decrease bimolecular salvation [24]. This dehydration leads to hydrophobic interactions and counteracts repulsion forces, which drives bimolecular aggregation and precipitation on silica surface. Weak chaotropic salts, like sodium iodide and guanidinium salts, have limited ability to salt-out or precipitate proteins but are effectual nucleic acid precipitators. The same mechanism of chaotropic salt that provides silanol groups on silica surfaces drives the temporary formation of hydrogen bonding between nucleic acids and the surface. However, the weakness of this method is that the quality of obtained DNA is not usually high, and may inhibit PCR [7].

For the filters utilized in this study, where no chaotropic salts were used, the DNA most likely binds to the surface of the amino-coated $\mu \mathrm{PF}$ by means of electrostatic interaction between the positive charged amino groups, present on the surface due to APTES coating, and the negative charge on the DNA molecule. Figure 9 schematically illustrates

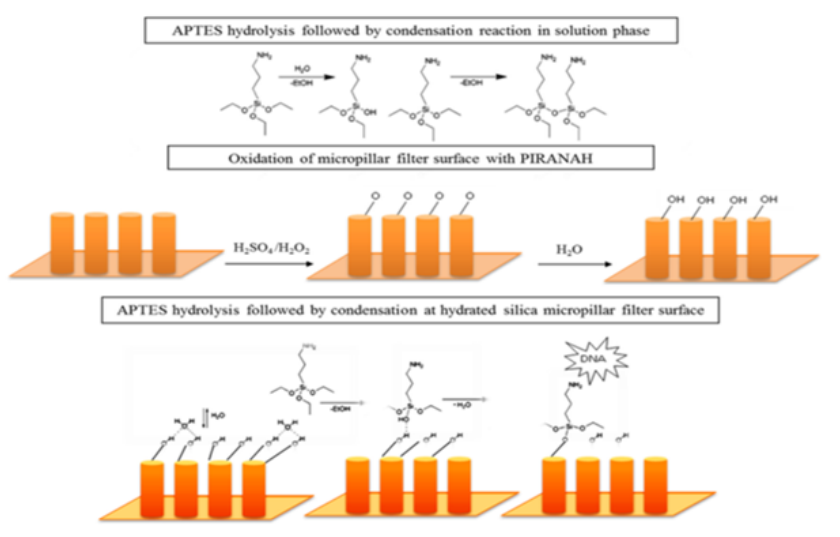

Figure 9: Schematic description of $\mu \mathrm{PF}$ silanization protocol. the mechanism for the liquid phase microfluidic deposition of APTES on to $\mathrm{Si} \mu \mathrm{PF}$. In the presence of water, as a solvent, APTES dimerizes to form a chain of intermediate silanol through a condensation reaction. Treating the surface of Si $\mu$ PF with Piranha prior to APTES coating, forms a thin silicon oxide layer. The subsequent water flow over this oxidized $\mu \mathrm{PF}$ surface causes its hydration. During the subsequent APTES coating flow, the water concentration on the surface of $S i \mu P F$ will decrease due to APTES hydrolysis, but remains primarily in solution, hence it becomes more likely that the unreacted APTES monomers will react with water in the system instead of with the water on the pillar surface. As the surface water is consumed during the silanization step, the deposited APTES can no longer attain a high degree of hydrolysis, leading to an increase of C:N bonds. After silanization, the surface of the $\mu \mathrm{PF}$ is washed with water to remove any unbounded APTES molecules and curedat $80^{\circ} \mathrm{C}$ for 4 hours to condense the APTES chain on the surface of Si $\mu \mathrm{PF}$ via water removal and to form the -Si-o-Si- bond. The mechanism described above suggests that DNA collection, based on electrostatic interaction between positive charge of APTES amino groups and negative charge of DNA sample, was performed [25,26].

The binding of DNA to the surface of the uncoated Si $\mu$ PF is likely to be due to the presence of silanol groups on the surface, which were formed during the filter cleaning with piranha $\left(3 \mathrm{H}_{2} \mathrm{SO}_{4}: 1 \mathrm{H}_{2} \mathrm{O}_{2}\right)$ and its subsequent exposure to water. The presence of such silanol groups encourages the temporary formation of hydrogen bondsbetween nucleic acids and the surface. Evidence of such weak binding is found in the high amount of DNA in the non-trapped and washed eluents, as shown in Figure 4F. However, the binding capacity of the uncoated filter is limited, compared to the well-established performance of the APTES-coated one. For example, starting with $2000 \mathrm{ng}$ of DNA loading, the overall DNA elution recovery $\%$ for amino-coated $\mu \mathrm{PF}$ is $52 \%$, compared to only $18 \%$ for an uncoated filter under similar conditions.

The simple and effective washing and eluting steps used in this work are important aspects of this study. For the washing step, pH 7.4 PB was utilized while the elution step was carried out using pure water at $80^{\circ} \mathrm{C}$. The use of hot water during the elution step allowed for direct detection of obtained DNA using UV Nano-Droplet, eliminating the need for using fluorescence intercalating dyes and fluorometer. The mechanism for our successful DNA elution step is likely to be attributed to thermodynamic instability, caused by the flow of hot water which may weaken the electrostatic interaction between DNA and APTES molecule that subsequently leads to the detachment of the DNA. The postulate for thermal instability stemmed from observation that denaturing of the DNA molecules is quite likely at elevated temperature. For example, hydrogen bonds between the nitrogenous bases in chromosomal DNA begin to weaken at $70^{\circ} \mathrm{C}$, causing the DNA molecules to buckle and change their configurations [27]. Such buckling of the DNA molecule affects the number of sites to which ions can bind. Another potentially contributing factor to the DNA detachment is the straining of both the bonds and the DNA molecule at high temperature, which clearly affects the available sites for hydrogen bonding and hydration of the DNA molecules.

Compared to available commercial filter kits, the described coated$\mu \mathrm{PF}$ device described in this work represents a strong candidate for $\mathrm{DNA}$ extract ion technology. For instance, a coated- $\mu \mathrm{PF}$ requires minute sample volume (only $10 \mu \mathrm{l}$ ) while using a commercial kit requires at least10 times that volume. In case of unavailability of sufficient sample volume, excessive dilution may be needed. Moreover, with coated$\mu \mathrm{PF}$, there is no need to centrifuge or to use organic solvents that may inhibit PCR or require a long time to incubate the sample. The 
capturing capacity of the coated $\mu \mathrm{PF}$ was significantly higher than that of the uncoated filter: $\sim 186 \mathrm{ng} / \mathrm{cm}^{2}$ capturing capacity is obtained using APTES-coated filters, compared to $\sim 49 \mathrm{ng} / \mathrm{cm}^{2}$ with uncoated filter. This reflects the important and beneficial role of the APTES coating combined the power of having a functionalized massive surface area for DNA purification.

\section{Conclusion}

In this study, the performance of a microfluidic silicon $\mu \mathrm{PF}$ device capable of capturing and eluting DNA from small sample volumes under continuous flow rate mode, was investigated and presented. Only four minutes were needed to execute experiment with even using the lower loading flow rate $5 \mu \mathrm{l} / \mathrm{min}$. Results show that the capture efficiency and elution \% are decreasing with increasing flow rate and this behavior is more pronounced at higher initial DNA loading. As a result, excellent filter results are obtained combining a low flow rate with low initial DNA loading, such as an elution recovery of $80 \%$, achieved at a flow rate of $5 \mu \mathrm{l} / \mathrm{min}$ and DNA loading of $250 \mathrm{ng}$. An uncoated $\mu \mathrm{PF}$ with identical pillar and macroscopic dimensions as the tested APTES-coated filter was also examined and showed limited capability for capturing DNA, which was traced back to Si pillar surface oxidation during the filter cleaning and preparation step. In addition to its excellent filtering capacities, the described DNA extraction $\mu \mathrm{PF}$ device exhibits interesting possibilities regarding monolithic integration with other micro-architectures to realize a fully integrated $\mu \mathrm{TAS}$ for use in the development of a variety of genetic diagnostics.

Building on the results of the work presented, an investigation of the optimum conditions to purify DNA from whole blood sample using APTES coated $\mu \mathrm{PF}$ is warranted. In addition, further work is needed to identify and characterize a suitable cleaning process to restore the $\mu \mathrm{PF}$ to its state before being used for DNA extraction. Such work is critical for determining whether such $\mu \mathrm{PF}$ can be reused.

\section{References}

1. Chen X, Cui DF, Liu CC, Li H (2007) Fabrication of DNA purification microchip integrated with mesoporous matrix based on MEMS technology. Microsystem Technologies 14: 51-57.

2. Manz A, Graber N, Widmer HM (1990) Miniaturized total chemical analysis systems: A novel concept for chemical sensing. Sensors and Actuators B: Chemical 1: 244-248.

3. Fan ZH, Mangru S, Granzow R, Heaney P, Ho W, et al. (1999) Dynamic DNA hybridization on a chip using paramagnetic beads. Analytical chemistry 71 : 4851-4859.

4. Shamansky LM, Davis CB, Stuart JK, Kuhr WG (2001) Immobilization and detection of DNA on microfluidic chips. Talanta 55: 909-918.

5. Wang J, Chatrathi MP, Mulchandani A, Chen W (2001) Capillary electrophoresis microchips for separation and detection of organophosphate nerve agents. Analytical chemistry $73:$ 1804-1808

6. West J, Boerlin M, Jadhav AD, Clancy E (2007) Silicon microstructure arrays for DNA extraction by solid phase sample contacting at high flow rates. Sensors and Actuators B: Chemical.

7. Kieleczawa DJ (2008) DNA Sequencing II Dealing with Difficult Template. Jones and Bartlett Publishers, Sudbury, Massachusetts, USA

8. Melzak KA, Sherwood CS, Turner RFB, Haynes CA (1996) Driving Forces for DNA Adsorption to Silica in Perchlorate Solutions. Journal of Colloid and Interface Science 181: 10.

9. Bienvenue JM, Legendre LA, Ferrance JP, Landers JP (2010) An integrated microfluidic device for DNA purification and PCR amplification of STR fragments. Forensic science international Genetics 4: 178-186.

10. Butler JM (2005) Forensic DNA Typing: Biology, Technology, and Genetics of STR Markers. Elsevier Academic Press, SanDeigo, USA.
11. Easley CJ, Karlinsey JM, Bienvenue JM, Legendre LA, Roper MG, et al. (2006) A fully integrated microfluidic genetic analysis system with sample-in-answerout capability. Proceedings of the National Academy of Sciences of the United States of America 103: 19272-19277.

12. Legendre LA, Bienvenue JM, Roper MG, Ferrance JP, Landers JP (2006) A simple, valveless microfluidic sample preparation device for extraction and amplification of DNA from nanoliter-volume samples. Analytical chemistry 78 : 1444-1451.

13. Butler JM (2001) Forensic DNA Typing: Biology \& Technology behind STR Markers. Academic Press, SanDeigo, USA.

14. Tian H, Hühmer AF, Landers JP (2000) Evaluation of silica resins for direct and efficient extraction of DNA from complex biological matrices in a miniaturized format. Analytical biochemistry 283: 175-191.

15. Cady NC, Stelick S, Batt CA (2003) Nucleic acid purification using microfabricated silicon structures. Biosensors \& bioelectronics 19: 59-66.

16. Yoza B, Arakaki A, Matsunaga T (2003) DNA extraction using bacterial magnetic particles modified with hyper branched poly amidoaminedendrimer. Journal of biotechnology 101: 219-228.

17. Chung Y-C, Jan M-S, Lin Y-C, Lin J-H, Cheng W-C, et al. (2004) Microfluidic chip for high efficiency DNA extraction. Lab on a chip 4: 141-147.

18. Oster J, Parker J, à Brassard L (2001) Polyvinyl-alcohol-based magnetic beads for rapid and efficient separation of specific or unspecific nucleic acid sequences. Journal of Magnetism and Magnetic Materials 225: 145-150.

19. Hwang KY, Kwon SH, Jung SO, Namkoong K, Jung WJ, et al. (2012) Solid phase DNA extraction with a flexible bead-packed microfluidic device to detect methicillin-resistant Staphylococcus aureus in nasal swabs. Analytical chemistry $84: 7912-7918$.

20. Nakagawa T, Tanaka T, Niwa D, Osaka T, Takeyama H, et al. (2005) Fabrication of amino silane-coated microchip for DNA extraction from whole blood. Journal of biotechnology 116: 105-111.

21. Hiraoka M, Fiorini P, Zhang L, De Malsche W, Majeed B, et al. (2010) Integrated fluidic system for bio-molecule separation. Conference proceedings: Annual International Conference of the IEEE Engineering in Medicine and Biology Society IEEE Engineering in Medicine and Biology Society Conference 2010: 6514-6517.

22. Hegab H, Soliman M, Attia S, Stakenborg T, Fiorini P (2012) No Title. $2^{\text {nd }}$ Saud International Nanotechnology Conference. Riyadh, Saudi Arabia.

23. Christel LA, Petersen K, McMillan W, Northrup MA (1999) Rapid, automated nucleic acid probe assays using silicon microstructures for nucleic acid concentration. Journal of biomechanical engineering 121: 22-27.

24. Vogelstein B, Gillespie D (1979) Preparative and analytical purification of DNA from agarose. Proceedings of the National Academy of Sciences of the United States of America 76: 615-619.

25. Kallury KMR, Macdonald PM, Thompson M (1994) Effect of Surface Water and Base Catalysis on the Silanization of Silica by (Aminopropyl)alkoxysilanes Studied by X-ray Photoelectron Spectroscopy and 13C Cross-Polarization/ Magic Angle Spinning Nuclear Magnetic Resonance. 10: 492-499.

26. Vandenberg ET, Bertilsson L, Liedberg B, Uvdal K, Erlandsson R, et al. (1991) Structure of 3-aminopropyl triethoxysilane on silicon oxide. Journal of Colloid and Interface Science 147: 103-118.

27. Enping H, Kiat HC, Samper V, Yu C, Jen LH, et al. (1996) Dependence of DNA adsorption to silicon dioxide on incubation temperature and time. 